\title{
Rice seeds vigor through image processing of seedlings
}

\section{André Pich Brunes ${ }^{*}$ (D) Ádamo de Souza Araújo ${ }^{2}$ Letícia Winke Dias $^{1}$ Júlio Antoniolli $^{1}$ Gizele Ingrid Gadotti ${ }^{2}$ Francisco Amaral Villela ${ }^{2}$} ${ }^{1}$ Universidade Federal do Rio Grande do Sul (UFRGS), 91540-000, Porto Alegre, RS, Brasil. E-mail: andre.brunes@gmail.com.
${ }^{*}$ Corresponding author.

${ }^{2}$ Universidade Federal de Pelotas (UFPel), Pelotas, RS, Brasil.

ABSTRACT: The aim of this paper was to verify the viability of digital image processing in the measurement of rice seedling and its potential use as seed vigor test. The experiment took place at the Laboratório Didático de Análise de Sementes, located in Capão do Leão (RS), using seeds of eight rice cultivars: Irga 424, Puitá Inta CL, BRS Esmeralda, SCS 116, Guri Inta CL, BRS Pampa, BRSGO Serra Dourada and Olimar. An image processing system (IPS) was used to measure length and area of shoot and root as an index of seed vigor in rice seeds. The experiment design was completely randomized with five replications. The evaluated variables were root and shoot length in graded ruler and by image, root and shoot area, and field emergence. Results obtained with the IPS were correlated with other quality tests though the Pearson tests. Determination of shoot length and leaf area of the seedlings obtained through IPS is effective for assessing the vigor of rice seeds. Key words: Oryza sativa, seedling length, leaf area, root area.

\section{Determinação do vigor de sementes de arroz através do processamento} de imagens de plântulas

RESUMO: $O$ objetivo neste trabalho foi verificar a viabilidade do processamento digital de imagens na mensuração de plântulas de arroz e sua potencial utilização como teste de vigor em sementes. O experimento foi realizado no Laboratório Didático de Análise de Sementes, localizado no Capão do Leão (RS), utilizando sementes de oito cultivares de arroz: Irga 424, Puitá Inta CL, BRS Esmeralda, SCS 116, Guri Inta CL, BRS Pampa, BRSGO Serra Dourada e Olimar. Uma ferramenta de processamento de imagens (FPI) foi utilizada para mensurar o comprimento e a área da parte aérea e de raizes de plântulas de arroz de modo a classificar as sementes em niveis de vigor. $O$ delineamento experimental foi inteiramente casualizado com cinco repetições. As variáveis avaliadas foram comprimento de raiz e parte aérea em régua graduada e pela imagem, área de raiz e parte aérea e emergência a campo. Os resultados obtidos com o FPI foram correlacionados com outros testes de qualidade por correlação de Pearson. A determinação do comprimento de parte aérea e área foliar de plântulas obtidos através do FPI é efetivo para avaliar o vigor de sementes de arroz.

Palavras-chave: Oryza sativa, comprimento de plântula, área foliar, área de raiz.

\section{INTRODUCTION}

Biophysical characteristics of plants are observed to determine the seeds vigor, such as the length and/or area of organs of developing seedlings, as suggested by the two world associations that congregate seed technologists (AOSA - Association of Official Seed Analysts / ISTA - International Seed Testing Association), according to VANZOLINI et al. (2007).

As examples, the determination of shoot and root length of the seedlings, in which 10-20 seedlings must have measured their shoot and root individually with a graduated ruler, according to the methodology described by NAKAGAWA (1999). This test; although, efficient for vigor measurement, requires a considerable amount of time and it is quite arduous because of the difficulties in positioning each of the seedlings during their measurement, and it may have a limited accuracy due to the irregular shape of seedlings (BRUNES et al., 2016).

Thus, digital image processing has been used to increase the accuracy of the results related to seedling biophysical standards, allowing larger sensibility in the classification of the lot of seeds in terms of level of vigor. The use of the software "Seed Vigor Imaging System ${ }^{\circledR}$ (SVIS), developed by Ohio State University allowed to detect differences of vigor between the lots of seeds of tomatoes and the reduction of vigor throughout the storage (SILVA \& CÍCERO, 2014). For determining lettuce seed vigor 
based on the root length, the efficiency of the software SVIS was considered high, for presenting small human interference, and the evaluated characteristics through the software allowed standardization of vigor tests, fast results and replicable in laboratories (KIKUTI \& MARCOS-FILHO, 2012).

Similar results were observed in the classification of sunflower seed vigor (ROCHA et al., 2015), and super-sweet corn seed (ALVARENGA et al., 2012). Although, the results of these software are promising, the present research shows routines developed for the digital image processing of rice seedlings with the math tool Matlab ${ }^{\circledR}$, obtained through digitalization in photocopier, and that can be used without the necessity of purchasing a software or specific equipment.

Given the above, this study aimed to verifying the digital image processing in the measurement of rice seedlings and its potential use as vigor test in seeds.

\section{MATERIAL AND METHODS}

The experiment was conducted at the Laboratório de Análise da Faculdade de Agronomia Eliseu Maciel - UFPel, located in Capão do Leão (RS) (Latitude $31^{\circ} 48^{\prime} 02.69$ 'S). Rice seeds of the cultivars Irga 424, Puitá Inta CL, BRS Esmeralda, SCS 116, Guri Inta CL, BRS Pampa, BRSGO Serra Dourada and Olimar were used, as they presented similar germination, different levels of vigor and no numbness, verified by preliminary tests. It consisted in the determination of the seeds physiological quality and vigor classification through various tests, comparing the results with those obtained from the seedlings image processing and experiment design was completely randomized with five replications.

The shooting (SL) and root length (RL) assessed on a graduated ruler (R) were performed with four subsamples of 20 seeds for each experimental unit in rolls of germination paper "germitest" type. Seeds were distributed in two straight lines longitudinal and staggered in the upper third of the paper and were placed in a germinator regulated at a constant temperature of $25^{\circ} \mathrm{C}$ (NAKAGAWA, 1999). After five days, the length of shoot and root of ten normal seedlings were individually measured up and then calculated the average length of shoot and root.

Field emergence (FE) conducted with four replications of 100 seeds in cultivation beds of $5 \mathrm{~m} \mathrm{x}$ $1.2 \mathrm{~m} \times 1.0 \mathrm{~m}$ filled with sifted soil, collected from a horizon A1 of a Planossoil haplic eutrofic solodic (EMBRAPA, 2013) belonging to the Pelotas mapping unit (STRECK et al., 2008). After the sowing, beds were irrigated daily, keeping the soil next to the field capacity. Evaluations were performed at 21 days after the sowing, determining the percentages of seedling emergence (NAKAGAWA, 1999).

After the determination of length of aerial part and root with graduated ruler, the seedlings were sliced, separating the aerial part from the root part. Afterwards, samples were digitalized with resolution of $200 \mathrm{dpi}$ (pixels per inch) in photocopier of the brand HP, model 2050, Corvallis/OR/USA. Dimension of pixel was determined obtaining image of a regulated ruler. Then, counting vertically the number of pixels existing between $10 \mathrm{~mm}$ in the ruler, it is obtained the number of pixels. Using a ruler of simple three was calculated the width of pixel in mm.

Routine were developed in the Matlab ${ }^{\circledR}$ for image processing, with the idea of converting the colorful image of seedlings into a black and white image (binary), where all pixels of the seedlings get white with value ("1") and the pixel from the background get black with value ("0").

Once the binary image is obtained, it was used an algorithm to separate the shoots from the root. This algorithm constituted in performing a cut in the image in the seed level, which originated the seedling, thus, being separated into two parts. For determining the length of the seedling, it was applied an algorithm of skeletonization in the binary image which consists in creating an inner skeleton in the image passing through middle points throughout the image. This skeleton presents unitary width, allowing the measurement of distance between two pixels.

The length of shoots and the length of the roots by processing of image (I) was determined through a routine in which the software detects a dot of the structure extremity to be measured and calculates the distance to the next near dot. Getting to the end of the structure the software detects that the other pixel of the extremity, without neighbor finishing the measure of that structure, thus, returning to search another structure in the image. After each reading of one structure the same is removed from the image and the process continues until there is none structure (BRUNES et al., 2016).

In the measurement of leaf and root area from the binary image was carried out by conducting the counting of all white pixels (" 1 ") that the images contained. With this, the remaining pixels were considered for the calculation of the area considered the software routine.

The normality of the data was analyzed by the Shapiro-Wilk test and the analysis of variance 
by the $\mathrm{F}$ test at $5 \%$ probability. The Pearson test correlated the response variables, and the $\mathrm{F}$ test compared the methodologies for determining the shoot and root length through measurement with a graduated ruler and image processing at 95\% probability. Experiment design was completely randomized with five replications. The Tukey test at $5 \%$ probability compared the averages among the cultivars. The R Software ${ }^{\circledR}$, version 3.1.1 and the data packet "ExpDes.pt" (BANZATO \& KRONKA, 2006; R CORE TEAM, 2014).

\section{RESULTS AND DISCUSSION}

There was a significant correlation at $1 \%$ probability of error in the results of the Field emergence test with the outcome of the shoot and root length of seedlings measured by digital image processing and seedling leaf area obtained by digital image processing (Figures 1a, 1b and 2a).

Although, the emergence test in the field and the tests based in biophysical parameters of seedling differs in terms of sensibility in the determination of vigor of the seeds, once, according to MARCOS-FILHO (2015) in the deteriorative process, reduction of size of seedlings is affected before the reduction of plants stands in the field, the use of image processing has offered $70 \%$ of correlation between results presented of the aerial part (Figure 1a) and the leaf area (Figure 2a) with the seedling emergence in the field. Thus, length tests of aerial part and leaf area could have been more sensitive in determining the vigor, and the environmental conditions during the conduction of
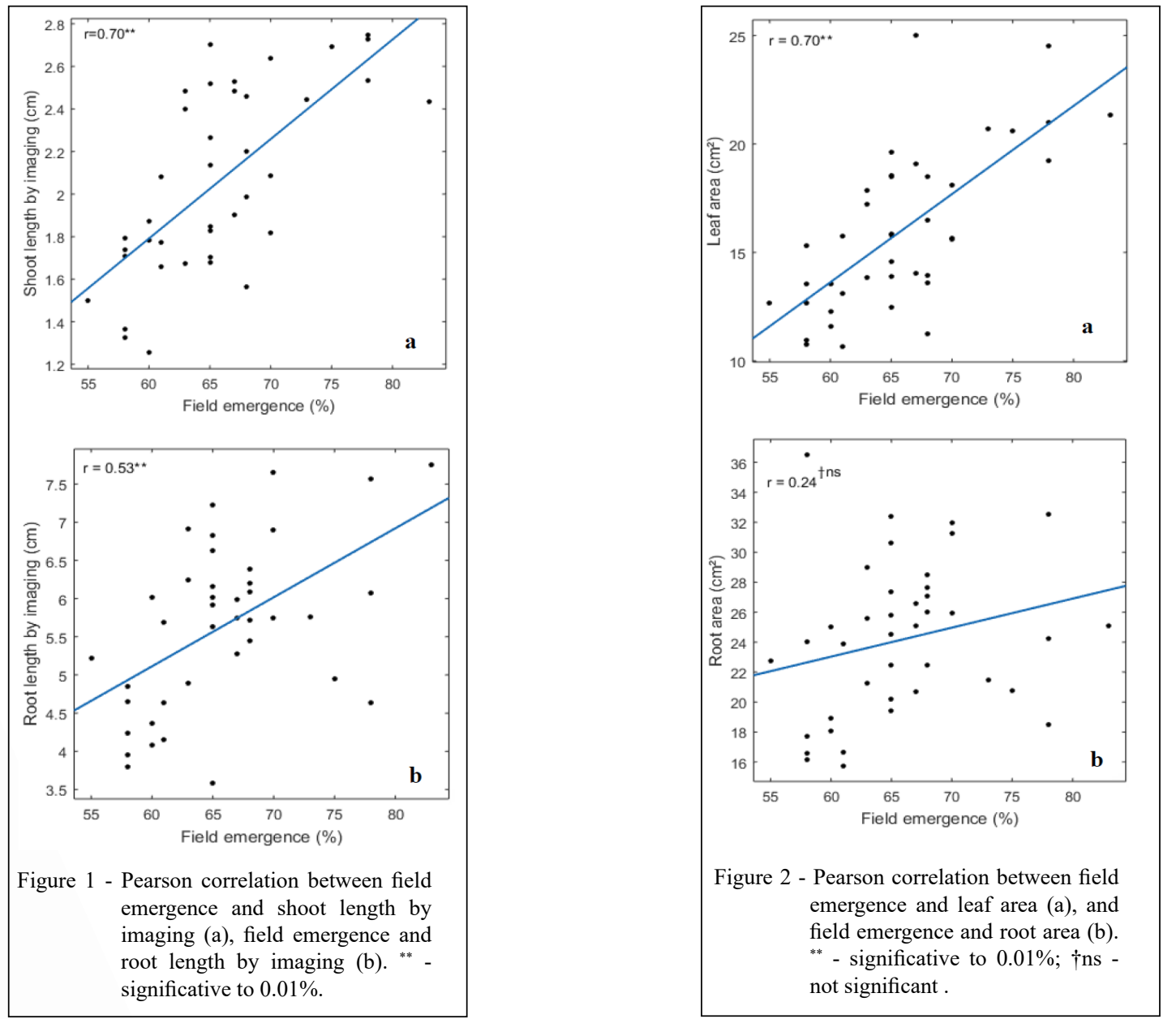

Ciência Rural, v.49, n.8, 2019. 
the test of emergence in field, which were not the most suitable to detect differences in vigor.

Conversely, the root length presented only $53 \%$ of the correlation with the emergence test in the field (Figure 1b), and the root area has not significant correlation (Figure 2b). This can be attributed to the fact that the development of roots in rice seedlings can be strongly influenced by genetic heritage, and less influenced by seed vigor (REDOÑA \& MACKILL, 1996), allowing the inference that the biometric determinations of seedling roots cannot be a good parameter related to vigor of rice seeds.

The high correlation observed between the shoot and root length tests measured by graduated ruler and obtained by digital image processing demonstrated a trend for a very similar variation in the results, which is crucial so that digital image processing can replace routine evaluations (Figures $3 a$ and $3 b$ ).

Whereas length of shoots measured by rule enabled classify the cultivars in two different levels of vigor, the same test measured through the digital processing of images allowed to classify the cultivars in four levels of vigor, similarly to the one obtained in the test of emergence in the field (Table 1). In both tests (SLI and FE) the cultivars BRS Pampa and Irga 424 presented the smaller results and the cultivar INIA Olimar was superior; although, in the SLI test did not differ from cultivars SCS 116 and Guri Inta CL. It should be highlighted that the use of the digital image

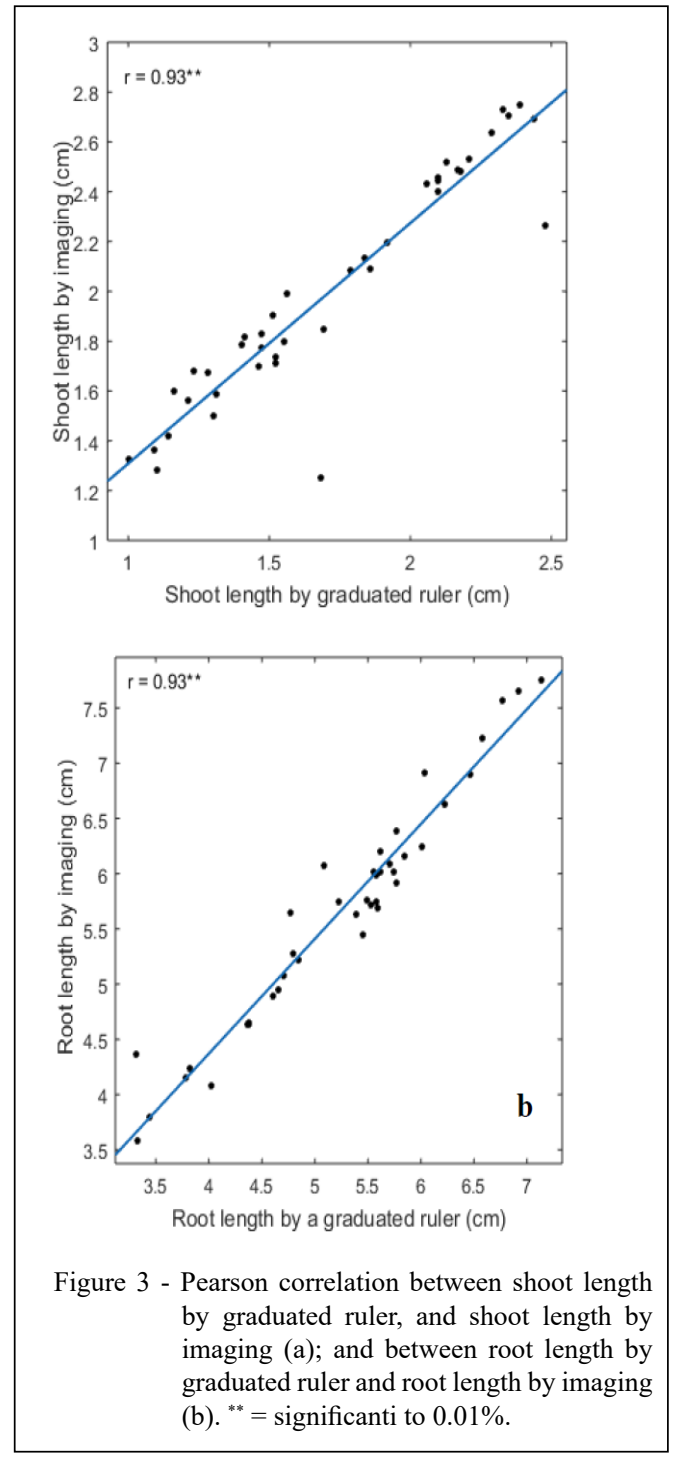

Ciência Rural, v.49, n.8, 2019. 
Table 1 - Shoot length by ruler (SLR), shoot length by image (SLI), leaf area (LA) and field emergence (FE) of plants of eight rice cultivars.

\begin{tabular}{|c|c|c|c|c|}
\hline Cultivar & SLR $(\mathrm{cm})$ & $\mathrm{SLI}(\mathrm{cm})$ & $\mathrm{LA}\left(\mathrm{cm}^{2}\right)$ & $\mathrm{FE}(\%)$ \\
\hline BRS Esmeralda & $2.00^{*} \mathrm{ab}$ & $2.20 \mathrm{~b}$ & $15.57 \mathrm{~cd}$ & $68 \mathrm{~b}$ \\
\hline Puitá Inta CL & $1.62 \mathrm{bc}$ & $1.87 \mathrm{c}$ & $14.71 \mathrm{cde}$ & $61 \mathrm{c}$ \\
\hline SCS116 & $2.20 \mathrm{a}$ & $2.53 \mathrm{a}$ & $20.46 \mathrm{ab}$ & $67 \mathrm{~b}$ \\
\hline INIA Olimar & $2.29 \mathrm{a}$ & $2.63 \mathrm{a}$ & $21.34 \mathrm{a}$ & $78 \mathrm{a}$ \\
\hline Irga 424 & $1.41 \mathrm{c}$ & $1.66 \mathrm{~cd}$ & $12.69 \mathrm{de}$ & $59 \mathrm{~d}$ \\
\hline Guri Inta CL & $2.06 \mathrm{a}$ & $2.38 \mathrm{ab}$ & $17.23 \mathrm{bc}$ & $66 \mathrm{~b}$ \\
\hline BRS Pampa & $1.28 \mathrm{c}$ & $1.48 \mathrm{~d}$ & $11.62 \mathrm{e}$ & $60 \mathrm{~d}$ \\
\hline BRSGO Serra Dourada & $1.41 \mathrm{c}$ & $1.76 \mathrm{~cd}$ & $14.35 \mathrm{cde}$ & $67 \mathrm{~b}$ \\
\hline C.V. $(\%)$ & 10.72 & 7.71 & 11.43 & 4.23 \\
\hline
\end{tabular}

${ }^{*}$ Means followed by the same lower-case letter in the column do not differ from each other by the Tukey test $(\mathrm{p} \leq 0,05)$.

processing has reduced the coefficient of variation in $3.01 \%$, which can result in higher precision in the results and bigger correspondence with the test of field emergence.

The leaf area obtained through the digital image processing allowed to classify the cultivars in five levels of vigor, identifying smaller results in the cultivars BRS Pampa, BRSGO Serra Dourada and Irga 424 and better performance in the cultivar INIA Olimar and SCS 116 (Table 1).

Likewise, according to the results obtained in this study, the software developed through the Matlab mathematical tool, permitted to assess, in a practical and efficient way, the vigor of rice seeds through digital image processing of seedlings, scanned in a common copier.

\section{CONCLUSION}

The determination of shoot length and leaf area of seedlings obtained by digital image processing is effective for assessing the vigor of rice seeds.

\section{DECLARATION OF CONFLICT OF INTERESTS}

The authors declare no conflict of interest. The founding sponsors had no role in the design of the study; in the collection, analyses, or interpretation of data; in the writing of the manuscript, and in the decision to publish the results.

\section{AUTHORS' CONTRIBUTIONS}

The authors contributed equally to the manuscript.

\section{REFERENCES}

ALVARENGA, R. et al. Avaliação do vigor de sementes de milho super doce por meio da análise computadorizada de imagens de plântulas. Revista Brasileira de Sementes, v.34, n.3, p.488 494, 2012. Available from: <http://dx.doi.org/10.1590/S010131222012000300017>. Accessed: Jan. 18, 2018. doi: 10.1590/ S0101-31222012000300017.

BANZATO, D.A.; KRONKA, S. N. Experimentação agrícola. 4.ed. Jaboticabal: Funep, 2006. 237p.

BRUNES, A.P. et al. Seedling length in wheat determined by image processing using mathematical tools. Revista Ciência Agronômica, Fortaleza, v.47, n.2, p.374-379, 2016. Available from: $\quad<$ http://www.scielo.br/scielo.php?script=sci_arttext\&pid $=$ S1806-66902016000200374 $>$. Accessed: Jan. 18, 2018. doi: 10.5935/1806-6690.20160044.

EMBRAPA. Empresa Brasileira de Pesquisa Agropecuária. Centro Nacional de Pesquisa de Solos. Sistema brasileiro de classificação de solos. 3.ed. Brasília, 2013. 353p.

KIKUTI, A.L.P.; MARCOS-FILHO, J. Testes de vigor em sementes de alface. Horticultura Brasileira, v.30, n.1, p.4450, 2012. Available from: <http://dx.doi.org/10.1590/S010205362012000100008>. Accessed: Nov. 11, 2017. doi: 10.1590/ S0102-05362012000100008.

MARCOS-FILHO, J. Fisiologia de sementes de plantas cultivadas. 2.ed., Londrina: ABRATES, 2015. 660p.

NAKAGAWA, J. Testes de vigor baseados no desempenho das plântulas. In: KRZYZANOWSKI, F.C.; VIEIRA, R.D.; FRANÇANETO, J.B. Vigor de sementes: conceitos e testes. Londrina: ABRATES, 1999. Cap.2, p.9-13. 
R CORE TEAM. R: A language and environment for statistical computing. R Foundation for Statistical Computing, Vienna, Austria. 2014. Available from: <http://www.R-project.org/>. Accessed: Nov. 21, 2017.

SILVA, V.N.; CICERO, S.M. Image Seedling to evaluate tomato seed physiological potential. Revista Ciência Agronômica, v.45, n.2, p.327-334, 2014. Available from: <http://www.scielo.br/pdf/ rca/v45n2/a14v45n2.pdf>. Accessed: Nov. 21, 2017. doi: 10.1590/ S1806-66902014000200014.

REDOÑA, E.D.; MACKILL, D.J. Mapping quantitative trait loci for seedling-vigor in rice using RFLPs. Theoretical and Applied Genetics, v.92, n.3-4, p.395-402, 1996. Available from: <https:// www.ncbi.nlm.nih.gov/pubmed/24166263>. Accessed: Nov. 07, 2017. doi: 10.1007/BF00223685.
ROCHA, C.R.M. et al. Avaliação do vigor de sementes de girassol por meio de análise de imagens de plântulas. Ciência Rural, v.45, n.6, p.970-976, 2015. Available from: <http://dx.doi. org/10.1590/0103-8478cr20131455>. Accessed: Nov. 07, 2017. doi: $10.1590 / 0103-8478 \mathrm{cr} 20131455$.

STRECK, E.V. et al. Solos do Rio Grande do Sul. 2.ed. Porto Alegre: EMATER/RS-ASCAR, 2008. 222p.

VANZOLINI, S. et al. Teste de comprimento de plântula na avaliação da qualidade fisiológica de sementes de soja. Revista Brasileira de Sementes, v.29, n.2, p.90-96, 2007. Available from: <http:// dx.doi.org/10.1590/S0101-31222007000200012>. Accessed: Nov. 02, 2017. doi: 10.1590/S0101-31222007000200012. 